\title{
THE FUTURE FARMING POTENTIAL OF
}

CENTRAL OTAGO

\section{W. A. LunN}

Farm Advisory Officer, Department of Agriculture, Ranfurly

M. L. Sмetham

Farm Advisory Officer, Department of Agriculture, Alexandra.

\section{Introduction}

Central Otago has often been referred to as the "land of rocks and lizards", implying that little else is able to survive. This was certainly true once, in the days of heavy rabbit infestation, when any sort of pasture improvement was wellnigh impossible. This situation existed even as late as $\mathbf{1 9 5} \mathbf{1}$, but now, with the rabbit controlled and a better knowledge of grassland improvement and management, stock and pasture are gradually taking over land that was at one time depleted scabweed and bare soil.

Of late, great interest has been shown in the potential of New Zealand for farming. This paper considers the potential of Central Otago by reference to the two counties, Vincent and Maniototo, which make up the core of the area, and examines the development methods by which this potential, a tremendous one, is being and will be attained.

\section{BASIS FOR Estimates}

The basis for the estimates of potential is that of soil type, the only logical ground for assessment when considering possibilities in farming. Soil type is, after all, a reflection of the soil-forming factors, parent material, time, primal vegetation, and, most important from the farmer's point of view, topography and climate (as rainfall). Particularly in an area which is the driest in New Zealand, climate as rainfall determines the species to be sown for fodder, and topography dictates the method of sowing these species. The interaction of parent material 
TABLE 1: PRESENT CARRYING CAPACITY (JUNE, 1964) AND ABSOLUTE POTENTIAL FOR THE

VINCENT AND MANIOTOTO COUNTIES

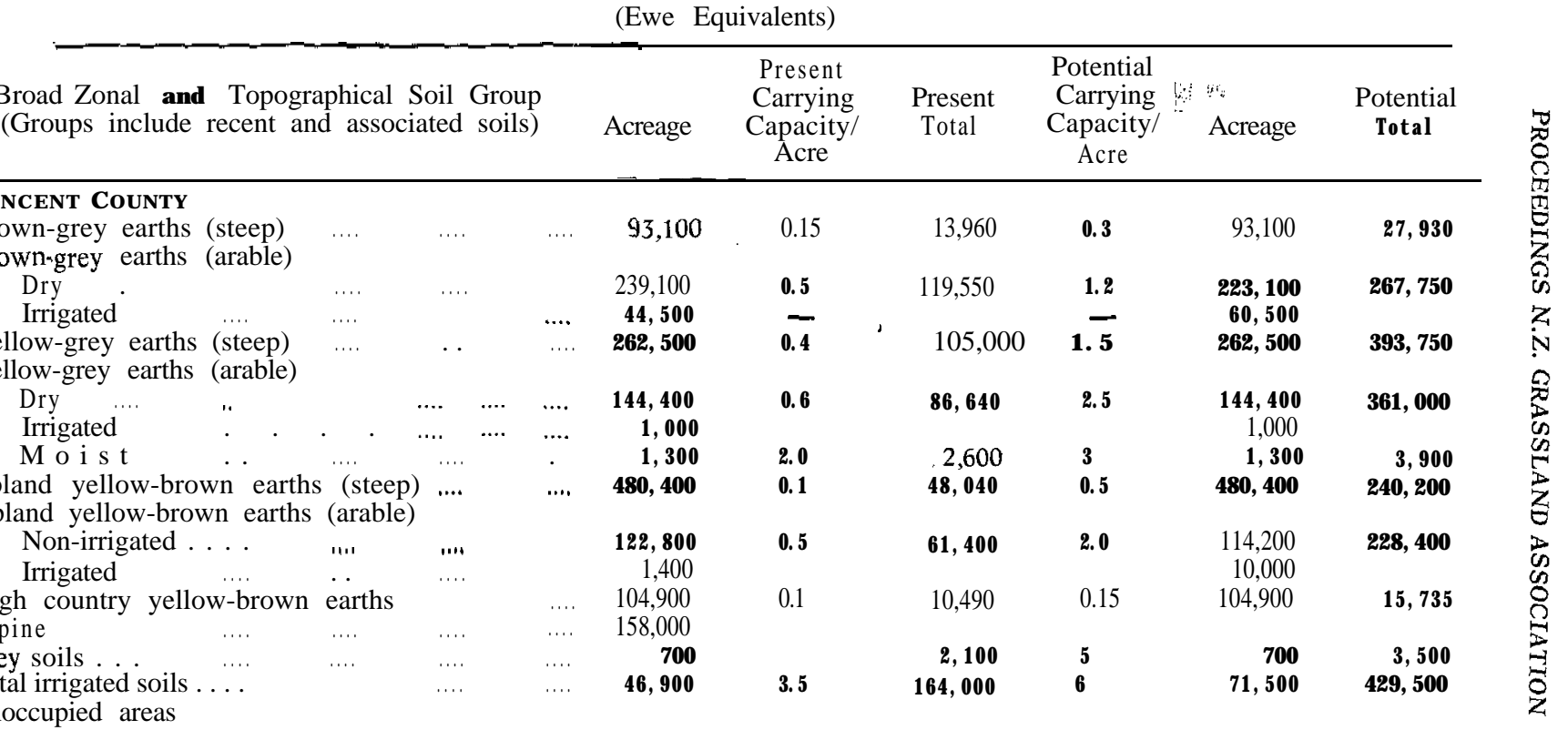

Alpine area, 158,000; plus 162,700 of upland

yellow-brown earths (steep)

320, 700

Lakes, rivers, tailings etc

$1,816,800$

Total Area

53. 200

603,930 
TABLE 1: PRESENT CARRYING CAPACITY (JUNE, 1964) AND ABSOLUTE POTENTIAL FOR THE VINCENT AND MANIOTOTO COUNTIES-continued (Ewe Equivalents)

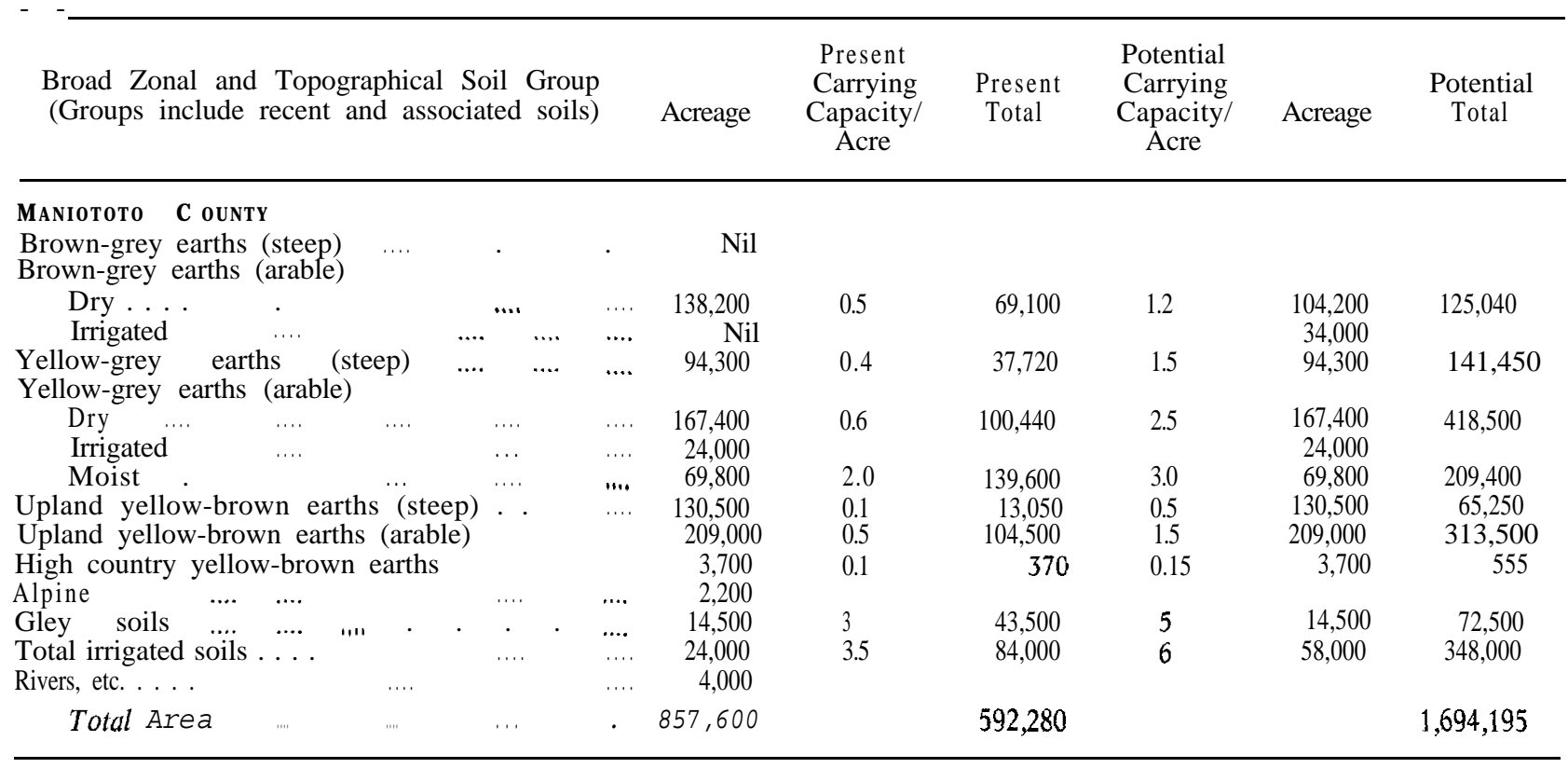


and climate also of course affects fertilizer requirements. Nevertheless, in Central Otago where the parent material is almost' entirely mica schist or greywacke, climate and topography are the two main points which determine potential.

Soils have therefore been arranged into broad zonal groups and further divided into (a) steep soils and (b) "arable" soils, i.e., those on which it is possible to operate a tractor. The acreages of the soil sets have been measured from the four mile to the inch soil map of the South Island, and the soils grouped by the Soil Bureau, D.S.I.R.

The acreages of soils lying in the broad zonal groups, i.e., soils arranged according to climatic influence, are now known, and knowing the proven methods by which these soils can be developed it is possible to calculate the absolute potential of these areas.

\section{Absolute Potential}

The stocking predictions which follow are in terms of absolute potential, i.e., the carrying capacity which would be obtained if every acre was developed to its ultimate using present knowledge, and assuming no limiting factors of, say, finance or labour. Absolute potential also assumes farm management to be at a good level.

Table 1 shows the grouping of the soils into zonal groups, the present carrying capacity, and future carrying capacity, for Vincent and Maniototo Counties in terms of ewe equivalents absolute potential.

Appendix A lists soil sets, with acreage, which make up the zonal groups.

\section{Realization of Potential}

What methods of development are being, and will be used to attain this potential? Each broad zonal group will be considered in turn.

\section{The Brown-grey Earths}

These soils have a very low annual rainfall of 13 to 17 in. Moisture levels are below field capacity for most of the year and below wilting point during the hot months. Winters are severe, frosts down to $20^{\circ}$ being fairly common, with as many as 180 frosts a year. This country is still 
recovering from the depredations of a very heavy rabbit population and vegetation varies from scabweed (Raoulia australis) and bare soil to quite well-clothed areas supporting Danthonia spp., blue wheatgrass ( Agropyrum scabrum), scattered plants of hard tussock (Festuca novaezealandiae), blue tussock (Poa colensoi), and silver tussock (Poa caespitosa). Sheeps sorrel (Rumex acetosella), haresfoot trefoil (Trifolium arvense) and drooping brome (Bromus tecforum) are common.

The brown-grey earths are very fertile soils although the reserve of available plant food is relatively low. The indications are that there is no response by legumes to phosphate, sulphur, or molybdenum (Ludecke, 1966).

\section{The Steep Brown-Grey Earths}

These are rocky and shallow. Present carrying capacity is estimated at 0.15 ewe equivalents per acre. Blocks of this country are normally big-4,000 acres and more-and rabbit eradication is proving difficult. To date, the only established method of improvement is by spelling during the seeding period of the native grasses (NovemberDecember) so encouraging increased establishment and ground cover of these. This coupled with lenient grazing after seeding and more subdivision does effect a remarkably quick improvement in cover (Hercus, 1961).

It is estimated that the carrying capacity can be raised from 0.15 to 0.3 ewe equivalents per acre.

Oversowing of these hill soils using white clovers and also lucerne with and without fertilizers has proved unsuccessful because of low rainfall.

\section{The Arable Brown-grey Earths}

Otherwise very similar to the steep soils, these are generally deeper. Because cultivation is possible, lucerne can be established and gives higher production than any of the other legumes. Even so, under the low rainfall of $15 \mathrm{in}$. average, production is only about 3.5 bales of hay plus some grazing approximately 1,400 to $1,600 \mathrm{lb}$ dry matter per year.

Lucerne at 7 to $8 \mathrm{lb}$ plus $1 \frac{1}{2} \mathrm{lb}$ cocksfoot is drilled if the stand is to be used for grazing, but if for hay, cocksfoot is usually omitted. 
In areas subject to wind erosion, or where the soil is bouldery, lucerne and cocksfoot can be sod seeded, i.e., sown direct into the native sward, but because there is no moisture conservation by cultivation, the seed rate has to be cut to $5 \mathrm{lb}$ lucerne and $1 \mathrm{lb}$ cocksfoot. The resultant stand, however, is not as productive as conventionally sown lucerne, having a lower plant density. One of the snags of wholesale improvement with lucerne is that either feed must be conserved or a feed crop sown to provide feed for a fairly long winter. Lucerne growth stops in April and really only gets going again in late September. This is different from a ryegrass pasture under higher rainfall where grazing over winter is possible if growth is autumn-saved.

Sheep, and particularly lambs, need an alternative feed to pure lucerne, otherwise thrift will suffer. Sowing cocksfoot with the lucerne overcomes this problem as does periodic grazing on adjacent native or improved tussock blocks.

In general, however, it is estimated that the considerable acreage of tractorable brown-grey earths at present carry 0.5 ewe equivalents per acre but that the potential is 1.2 ewe equivalents per acre.

\section{The Yellow-Grey EARTHS}

As a rough guide, these soils lie between the very dry brown-grey earths, and the wetter soils of the top half of the hills. Rainfall on the yellow-grey earths varies from 18 to $30 \mathrm{in}$. and they all experience a pronounced dry season. They often are below field capacity (moisture) for up to 5 months of the summer and moisture may sometimes be below wilting point at these times.

For the purposes of this paper, the arable yellowgrey earths have been further divided into dry (dry subhygrous and sub-hygrous) and moist (dry hygrous) soils. As the heading suggests, the dry soils lie mainly in the 18 to 22 in. rainfall group and the moist soils mainly in the 22 to 30 in. group.

The native vegetation on the yellow-greys consists mainly of hard and silver tussock, still sparse in places, since the vegetation, like that on the brown-greys, is also still recovering from a heavy rabbit population. A part from the 
tussock, which is much more evident on the yellow-greys, the other vegetation is similar to that described for the brown-grey earths.

\section{The Arable Yellow-grey Earths (Dry)}

Once the main plant nutrient deficiency of sulphur is corrected, these soils are very fertile. Reserves of plant food tend to be low and are fairly quickly depleted by cropping. Fifty pounds of sulphur applied as $11 / 2 \mathrm{cwt}$ sulphur superphosphate 400 every three years appears to be adequate for maintenance except where soils have previously been depleted.

As mentioned before, this group has a rainfall of 18 to 22 in. but this can vary widely from season to season. Where the rainfall is round $18 \mathrm{in}$., lucerne produces about 3,000 lb of dry matter, exceeding that produced by grassclover pastures. However, at the other end of the scale, under 22 in. rainfall, total production from both lucerne and grass is similar at round $4,500 \mathrm{lb}$ dry matter (M. L. Smetham, Zoc. cit.). Nevertheless, with the hot dry summers experienced, the production during the summer months from grass-white clover pastures is poor.

The best system of pastures for these areas is to have sufficient acreage in grass-clover sward to provide for autumn-saved pasture while the balance is sown to lucerne for hay, and lucerne/ cocksfoot for summer grazing.

It is estimated that the carrying capacity of this country is now 0.6 ewe equivalents per acre which with development could be raised to 2.5 ewe equivalents. A plant which needs serious consideration for these areas is subterranean clover. Some farmers sowed subterranean clover after the last war but were disappointed chiefly because the need for sulphur, inoculation, and higher seed rates was not appreciated. Some stands survive to this day and are quite impressive.

Indications from pilot variety trials in three different rainfall zones (15 in., 17 in. and 21 in.) in the Upper Clutha area comparing eighteen varieties of subterranean clover show that in the first year of the trials a number of varieties have been better producers than the presently available Mt. Barker and Tallarook and the most outstanding of these have been Nangeela and Woogenellup (M. L. Smetham, loc. cit). 
Although the production from subterranean clovers is unlikely to even equal lucerne, as a special purpose spring and autumn grazing proposition and as a pioneer legume, subterranean clover has a place. Some of its advantages, especially as a pioneer legume, are its ability to germinate on a rough seedbed, its rapid establishment, and its ability to survive under low fertility conditions. However, more experimental work is needed, particularly on the comparative production from lucerne, subterranean clover and pasture.

\section{The Arable Yellow-grey Earths (Moist)}

These soils along the foot of the ranges are an important group.

They enjoy a medium rainfall (20 in, to $30 \mathrm{in}$.) and are highly productive when deficiencies have been corrected. They are deficient in phosphate, sulphur and, in some cases, molydenum.

Development is the closest to what could be described as conventional development of any soil in the Central Otago area with ryegrass-white clover pastures being predominant with a high proportion of cocksfoot because of the low summer rainfall.

Natural cover is fescue tussock, annual grasses, with some stunted natural clovers and some browntop. The present carrying capacity is two ewe equivalents per acre and this could be increased to three.

$$
\text { The Steep Yellow-grey Earths }
$$

These lie on the lower slopes of the ranges which separate the valleys of Central Otago.

Extensive development is being carried out at present, more particularly on the eastern slopes, by oversowing with seed and fertilizer, and subdivision. Red and white clovers and cocksfoot form the basis of seed mixtures, with some alsike and more recently some ryegrass being included. The provision of airstrips and access roads is a very necessary part of the development of this country. The improvement of this steep hill country can be quite spectacular with fairly rapid establishment of red clover in particular.

Increases in lambing percentages and wool weights with a reduced death rate follow as a direct result of improve- 
ment. This type of development, which is fairly recent in Central Otago, means that the aim of all-grass farming must be kept firmly in mind even though this may not always be possible. Reserves of supplementary feed such as hay and silage need to be maintained.

This country is steep but extensive so that it would not be possible to hand feed the large numbers of stock which eventually would be carried on this country. Some farmers have actually reached the stage where, because of numbers of stock, the job of growing and carting, a large amount of hay has become a problem. Autumn-saved pasture and other labour saving techniques have had to be adopted.

The use of cattle is playing an increasingly important part in this country. The present carrying capacity is 0.4 ewe equivalent per acre while the potential is reckoned to be 1.5 ewe equivalents per acre.

\section{THE Yellow-Brown Earths}

\section{The Upland Yellow-brown Earths (Steep)}

The improvement of this country is similar to that of the steep yellow-grey earths of the foothills through oversowing, topdressing and subdivision.

On the mountain tops from an elevation of 3,500 up to about 4,500 ft, production at present is limited to summer grazing for ewes and the only permanent stock on a good deal of this country are wethers.

The rainfall here is good; the soils are deep in many places and the cover is mostly snowgrass (Danthonia flavescens).

Requirements for superphosphate are high and, of course, application costs are much higher, but by. the time the development of this country is really under way capital would be available from the improvement of the more readily improved lower country.

The growing season is short at this elevation being no more than three or four months of the year, but, with improvements, a slightly longer growing season could be expected.

Access by tracks to most of this country is now good, and the suggestion which has been made from time to time that this country could be considered only for watershed purposes is now being seriously reviewed. 
With oversowing, these soils which now carry 0.1 ewe equivalents per acre are estimated to be able to carry 0.5 ewe equivalents per acre.

\section{Arable Yellow-brown Earths}

The majority of these soils lie at altitudes of between 2,500 and 3,500 ft with a natural cover of mostly hard tussock and browntop. However, there is a substantial acreage of these soils in the Upper Clutha Valley at low altitude. Although these soils are yellow-brown earths they have to be farmed under a dry climate (similar to that of the dry yellow-grey earths) and development, sowing to mainly lucerne but with some ryegrass pastures, is the same as the latter.

A part from these anomalous soils, most of the arable yellow-browns are capable of growing ryegrass-white clover pasture although the growing season is much shorter than at valley floor level. Initial development will almost certainly be aerial. Sulphur, molybdenum and phosphate are needed initially on these soils with 2 cwt superphosphate as an annual maintenance dressing on sown ryegrass-white clover pastures.

Present carrying capacity is rated at 0.5 ewe equivalents and with improvement this could be increased to an average of 2.0 ewe equivalents/ acre.

\section{High Country Yellow-brown Earths}

These are the soils with a high rainfall of more than 50 in. which exist near the top of the mountain ranges. The vegetation is mainly sub-alpine with sparse snowgrass and herbs. Its use is confined to summer grazing for weaned ewes and wethers. Other than an easing of grazing pressure as feed becomes available at lower levels no development is warranted. Present carrying capacity is round 0.1 ewe equivalents per acre which would increase to 0.15 with improvement of cover.

\section{GLBY SoILS}

Because of fluctuating watertables and the fact that they are subject to flooding, the gley soils are being partially used only. These soils are highly fertile and could be among the most productive in the district. 
Their improvement would depend on extensive drainage mostly along the Taieri River. At the same time, even though most of these soils are flooded at times, they would eventually reach maximum production only through irrigation because of the low rainfall (15 to $17 \mathrm{in}$.). A carrying capacity of five ewe equivalents per acre should be possible on these soils.

\section{IRRIGATION}

At present, some soils of nearly all categories are being irrigated and the total irrigated area for both counties is 60,306 acres (Ministry of Works schemes) and an estimated 10,500 acres (private schemes $j$. Where rainfall is low and is combined with high summer temperatures, irrigation is essential for maximum per acre production. However, not all soils within the dry areas are suitable for irrigation because of uneven terrain or shallow depth. More important, water may not be available at a reasonable cost.

The Ministry of Works has estimated that the potential. for irrigation in the counties of Vincent and Maniototo is a further 58,600 irrigable acres.

Assuming farm management to be efficient, the other factor which will contribute to maximum stock carrying on irrigable land is efficient water use. This means using, as far as possible, border dykes to spread water evenly over every irrigable area, it means farm schemes must be designed to give equal water application down the whole length of each border, and it means that care must be taken not to over or under irrigate.

The fertilizer requirements of soils under irrigation depend on which zonal group they fall into. Irrigated brown-grey earths need some $3 / 4$ cwt superphosphate annually, irrigated yellow-grey earths $11 / 4 \mathrm{cwt}$, and irrigated yellow-brown earths 2 cwt. Periodical boosts of additional sulphur are needed every four years on the first two, but only the year after sowing out on the yellow-brown earths.

Data from trials (G. G. Cossens, pers. comm.) show that dry matter yield on even the shallow irrigated soils is usually 7,500 lb per year with deeper soils yielding 9,000 $\mathrm{Ib}$, and while 3.5 ewe equivalents is the estimated present carrying capacity, the potential is considered to be at least six ewe equivalents per acre. 
Appendix B lists present and possible future irrigation schemes.

$$
\text { Insurance Irrigation }
$$

Changes in the availability of water have brought about changes in use. With early irrigation, water was more easily obtained and costs were much lower. All irrigation was by gravity and the easiest supplies were naturally tapped first. In recent years, the cost of getting water has increased and many of the more recent irrigation schemes have involved pumping. The same applies to private irrigation schemes installed by individual farmers and the shortage of labour and the cost of labour have also helped to alter the picture.

On larger irrigated properties where water can be bought or pumped at a reasonable cost the pattern of farming has not changed substantially and it may not alter much in the near future. However, where higher costs of obtaining water are involved, up to $£ 3$ and $£ 4$ per acre for pumping plant, water is being used for highproducing winter feed and cash crops.

Development of many hill country farms is highly de pendent on a reliable supply of irrigation water to grow winter feed. To supply this type of irrigation, future schemes may have to consider this type of high cost per acre "insurance irrigation" rather than whole farm supplies because of high installation costs for the latter.

\section{Conclusion}

Central Otago has a tremendous potential. In Vincent County the largest increase will come from the aerial de velopment of the steep yellow-grey earths and upland yellow-brown earths totalling round 430,000 ewe equivalents, followed by development of the arable yellowgrey earths giving approximately an extra 280,000 ewe equivalents.

In Maniototo County, the biggest increase will come from development of the arable yellow-grey earths totalling round 310,000 ewe equivalents followed by an increase from irrigation of approximately 240,000 ewe equivalents.

The total potential is shown in Table 2. Speed of attainment of these figures is anybody's guess. Holdings are large in Central Otago (the average size of holding for 
TABLE 2: TOTAL POTENTIAL OF VINCENT AND MANIOTOTO COUNTIES

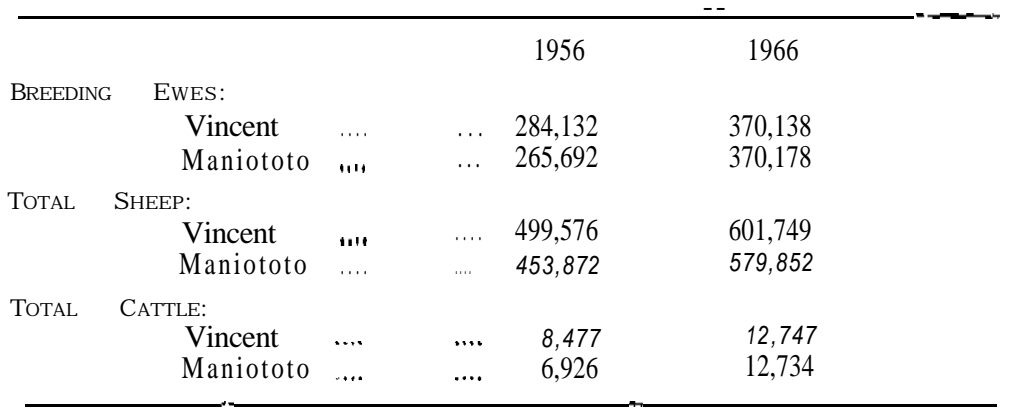

both Maniototo and Vincent Counties is approximately 3,000 acres) and it is often said that there is little incentive to develop; nevertheless considerable progress has been made in the last ten years.

The absolute potential of Vincent County is estimated at approximately three times present carrying capacity $(603,930$ ewe equivalents at present, and 1,971,665 absolute potential), while that for Maniototo County at almost three times present carrying capacity $(592,280$ ewe equivalents at present, and 1,659,295 absolute).

\section{Acknowledgements}

The writers gratefully acknowledge the help given by E. Cutler and M. J. Leamy of the Soil Bureau, D.S.I.R., in providing data for this paper.

\section{REFERENCES}

Hercus, J. M. 1961: N.Z. J. Agric., 103 (3) : 257

Ludecke, T. E. 1966: Proc. Int. Grassl. Cont. 


\section{APPENDIX A}

Acreages of Soll Sets in Zonal and Topographical

GROUPS

\section{VINCENT COUNTY}

Grouping and acreages extracted by Soil Bureau, D.S.I.R., from the 4 mile to the inch soil map.

1. Brown-grey Earths (Steep)

Alexandra steep

2. BROWN-GREY Earths (Arable)

Lowburn....

Drybread ....

Wetherburn

Linnburn ....

Waenga

Ripponvale",

Molyneux

Cromwell ....

Conroy

Conroy Hill

Clyde

Clare

Clare hill .....

Becks

\section{Soil Set Acreage}

.... $\quad 93,100$

.1.4 $\quad 17,500$

… 40,100

… $\quad 800$

.... 24,600

... $\quad 21,200$

4,900

… 20,000

.... $\quad 1,500$

... $\quad 20,000$

... $\quad 66,300$

13,600

... 900

… 12,400

$\quad 12,100$

$\quad 12,600$

.... 14,900

. . . 262,500

3. Yellow-Grey Earths (Steep) Arrow Steep

EARTHS (Arable)

4A. Dry Sub-hygrous and Sub-hygrous Pigburn

Middlemarch

Matakanui

Cluden

Tiroiti

Tiroiti

Blackstone

Blackstone Hil

Meyer Hill

Wanaka ...

Matarae

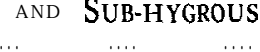

\section{.... 10,100}

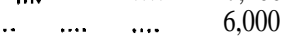

$\begin{array}{lll}\ldots & \cdots & \cdots\end{array}$

$\quad 800$

$\cdots, 700$
$\cdots$

... $\quad 29,500$

.... 51,500

.... $\quad 3,700$

$\cdots, 700$
$\cdots$

$\cdots \quad 4,800$

4AA.RELATED RECENT SOILS

Gladbrooke

7,200

1,300

Dry Hygrous

Naseby

... $\quad 1,300$
Acreage

Occupied

93,100

256,100

262,500

138,200 
FARMING POTENTIAL, CENTRAL OTAGO

5. Upland Yellow-Brown EARTHS (Steep)

\begin{tabular}{|c|c|c|}
\hline Kaikoura Steep & $\ldots \ldots$ & \\
\hline Dunstan Steep & & 330,800 \\
\hline ht & & 35,500 \\
\hline ht Steep & & 000 \\
\hline een & & $00^{*}$ \\
\hline 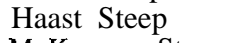 & & 21, \\
\hline err & & 48 \\
\hline
\end{tabular}

McKerron Steep $48,700^{*}$

6. Upland Yellow-Brown EarTHS (Arable)

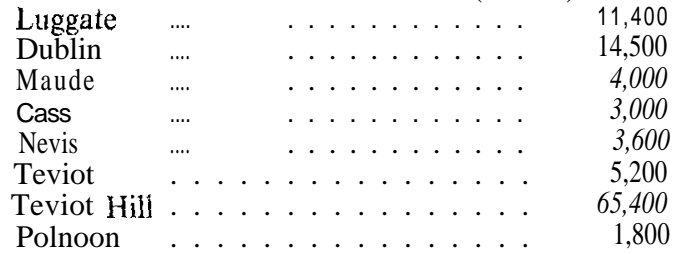

480,400

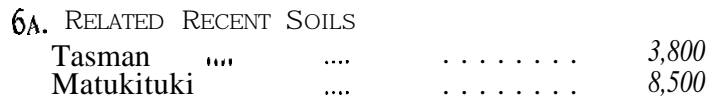

111,900

$8,500 \quad 12,300$

7. High COUNTRY Yellow-BROWN EARTHS 57,100

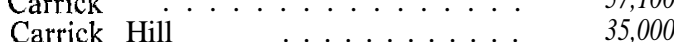

$\begin{array}{llll}\text { Carrick Hill } & \ldots \ldots \ldots \ldots \ldots & 35,000 \\ \text { Obelisk } & \ldots \ldots \ldots \ldots & 12,800\end{array}$

104,900

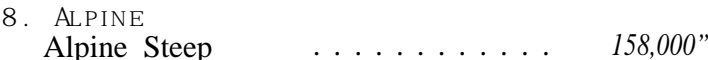

9. GLEY SoILs

Paerau

700

Total unoccupied soils ..........

320,700

Total soils acreage

LAKES $\quad \cdots \quad \ldots \ldots \ldots$

RIVERS $\quad \ldots \ldots \ldots \ldots$

GLACIERS $\quad \cdots \quad \ldots \ldots \ldots$

TAILINGS

Vincent County Total Area

$1,816,800$

33,800

122,200

'500

6,700

$1,870,000$

\section{MANIOTOTO COUNTY}

Grouping and acreages extracted by Soil Bureau D,S.I.R.

$\begin{array}{cc}\text { Acreage } \\ \text { Soil Set Acreage } & \text { Occupied }\end{array}$

1. BROWN-GREY EARTHS (Steep) Nil

2. BROWN-GREY EARTHS (Arable)

$\begin{array}{lrrrr}\text { Drybread ..." } & . . . & \ldots . & \ldots . & 23,000 \\ \text { Wetherburn } & \ldots . & \ldots & \ldots . & 21,500\end{array}$

*Unoccupied soils 


$\begin{array}{llllr}\text { Linnburn } & \ldots . & \ldots & \ldots & 11,000 \\ \text { Ranfurly . . . . } & \ldots & \ldots . & \ldots & 14,800 \\ \text { Conroy . . . } & \ldots & \ldots . & \ldots . & 1,800 \\ \text { Clare } \quad \ldots & \ldots & \ldots & \ldots & 800 \\ \text { Becks } \ldots . & \ldots & \ldots & \ldots & 20,800 \\ \text { Becks Hill } & \ldots & \ldots & \ldots & 1,500\end{array}$

2A. Related Recent Soils

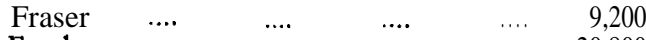

$\begin{array}{llllll}\text { Eweburn } & \ldots & \ldots . & \ldots . & & \\ & & \ldots . & \ldots . & \ldots & \end{array}$

30,000

2b. Associated Brown Granular Loams

$\begin{array}{lllll}\text { Camphill .... } & \ldots & \ldots & \ldots & \ldots\end{array}$

Camphill-Becks

3. Yellow-grey Earths (Steep)

Arrow Steep $\quad 72,200$

$\begin{array}{rrrrr}\text { Omarama Steep .... } & \ldots & \ldots & \ldots & 2,200\end{array}$

Tengawai Steep .... ....

94,300

4. Yellow-GRey Earths (Arable)

4A. DRY SUB-HYgROUS AND SUb-HygROUS

$\begin{array}{llllll}\text { Pigburn } & \ldots & \ldots & \ldots & \ldots & \\ \text { Middlemarch } & \ldots & & \end{array}$

Middlemarch $\quad$.... $\quad$..." $\quad$..." 10,400

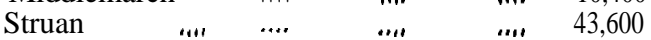

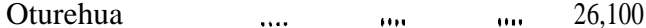

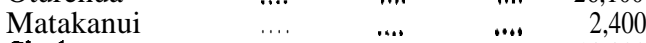

$\begin{array}{llllll}\text { Cluden } \quad . . & \ldots & \ldots & \ldots & \ldots & 13,300\end{array}$

$\begin{array}{lllll}\text { Tiroiti } & \ldots & \ldots & \ldots & \ldots\end{array}$

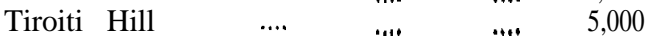

Blackstone Hill .... ... $\quad \ldots ., \quad 29,400$

Matarae $\quad 4,400$

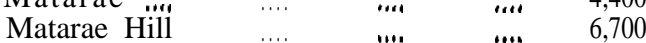

Hakataramea

189,200

4aA. Related Recent Soils

$\begin{array}{lllll}\text { Clutha } \quad . . & \ldots & \ldots & \ldots & \ldots\end{array}$

$\begin{array}{lllll}\text { Gladbrook } & \ldots . & \ldots & \ldots & \\ & \ldots . & \ldots & \ldots & 1.100\end{array}$

413. DKY HYgRous

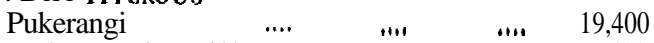

Pukerangi Hill ....

$\begin{array}{lllll}\text { Naseby . . . } & \ldots . . & \ldots & \ldots & \ldots, \\ & \ldots & \ldots . . & \ldots & 31,900\end{array}$

Tengawai Hill .... .... .... $12,100 \quad 69,800$

5. Upland Yellow-Brown Earths (Steep)

Kaikoura . . . . $\quad$ 9............ 95,200

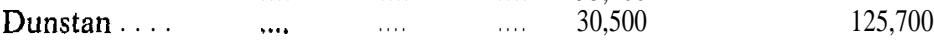

5A. Associated Brown Granular loams

Cargill ... $\ldots \quad \ldots \quad \ldots, \quad \ldots \quad 3,800$

Cargill Hill $\quad \ldots \quad \ldots . . . \quad 1,000$ 
6. Upland Yellow-brown Earths (Arable)

\begin{tabular}{|c|c|c|c|c|}
\hline OPLAIND & & \multirow{2}{*}{ 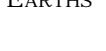 } & \\
\hline Cass & $\cdots$ & & & 9,900 \\
\hline Cass Hill & $\ldots$ & . & & 7,100 \\
\hline Wehenga Hill & . & & & 8,100 \\
\hline Hightop Hill & & & . & 20 \\
\hline Teviot & יו" & . & & 23,100 \\
\hline Teviot Hill & . & $\cdots$ & $\ldots$ & 142,600 \\
\hline Kirkleston & $\ldots$ & $\ldots$ & $\ldots$ & 4,800 \\
\hline Maungatua & $\ldots$ & $\ldots$ & $\ldots$ & 4,600 \\
\hline
\end{tabular}

$200,40 C$

6a. Related Recent Solls

Tasman ... . . ... 8,600

7. High Country Yellow-brown Earths

Puketeraki

$\begin{array}{lllll}\text { Puketeraki Hill } & \ldots . . & \ldots & \ldots . . & 500\end{array}$

$\begin{array}{lrrrrr}\text { Carrick Hill } & \ldots & \ldots & \ldots . & \ldots . & 400 \\ & & & \ldots & \ldots . & 2,800\end{array}$

3,700

8. Alpine

$\begin{array}{lll}\text { Alpine Steep } & \ldots & 2,200\end{array}$

9. GiEY SoILS

Dobson ....

Paerau $\ldots . . . \quad \ldots \quad r+1, \quad 11,500$

14,500

Total Soils Acreage $\quad \ldots \quad \ldots, \quad \ldots, \quad 853,600$

$\begin{array}{lllllr}\text { Rivers } & \ldots & \ldots & \ldots & \ldots & 4,000\end{array}$

$\begin{array}{lll}\text { Maniototo County Total Acrenpe } & \mathbf{8 5 7 . 6 0 0}\end{array}$ 


\section{APPENDIX B}

\section{IRRIGATION \\ SCHEMES, \\ Vincent and Maniototo \\ Counties \\ Central Otago}

\section{VINCENT}

\section{Present Schemes (Irrigable Areas) acres}

Ministry of Works schemes

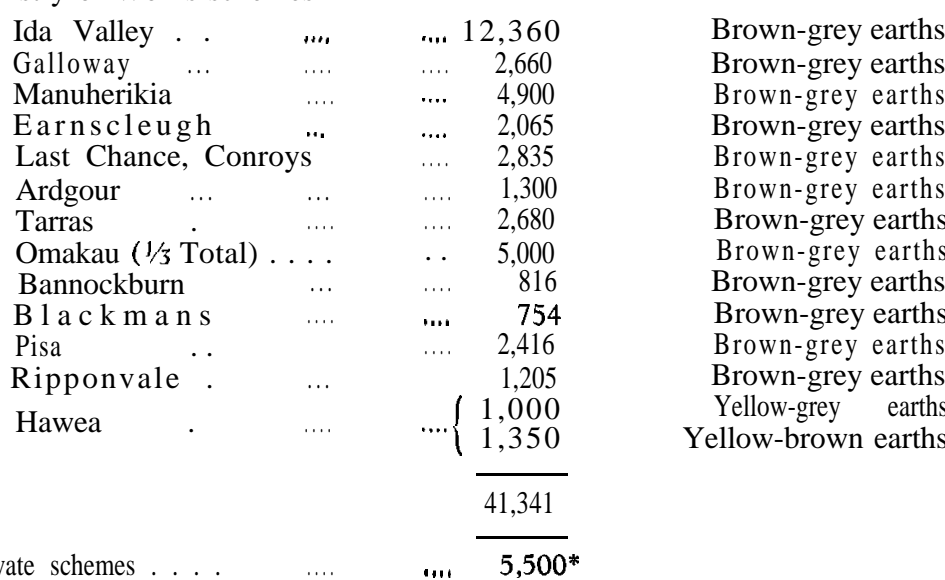

\section{Potential Irrigable Areas}

Moutere terraces

Upper Clutha

$$
\cdots \cdot \frac{\begin{array}{c}
13,000 \\
3,000 \\
8,600
\end{array}}{24,600}
$$

Brown-grey earths Brown-grey earths Yellow-grey earths

Present Schemes

Ministry of Works

$$
\begin{aligned}
& \text { Hawkdun } \\
& \text { Idaburn } \\
& \begin{array}{llll}
\cdots & \ldots & \ldots & 8,400
\end{array} \\
& (2 / 3 \quad \text { total }) \\
& \begin{array}{rrr}
\cdots & \cdots & \\
\cdots & \cdots & 10,000
\end{array} \\
& 18,965 \\
& 5,000
\end{aligned}
$$

\section{Potential Irrigable Areas}
Maniototo
Brown-grey earths

Yellow-grey earths Yellow-grey earths Yellow-grey earths *AUTHOR'S EST IMATES 
DISCUSSION

Is it worth bothering with country with a potential of a fraction of a sheep to the acre? Should not this be withdrawn from grazing and planted in trees for scenic development or for timber?

(SмEтhAm) : The country with this low potential lies at a height of about $4,500 \mathrm{ft}$ and above, It is mostly steep and inaccessible to vehicles and has a tough climate, being covered with snow for 5 to 8 months of the year. I doubt whether trees would survive and even if they did, growth would be very slow indeed.

(LUNN): This country is certainly not a timber proposition. The situation now is that it does provide grazing in February and March for wethers and weaned ewes, so spelling the lower country.

Comment (G. I. BANFIEID): Climate in these areas has favoured the development of a tussock association rather than one of trees.

(LUNN) : The area under discussion is generally not suitable for trees, but there are established State forests at Naseby and near Tapanui in heavier rainfall districts just outside the Central Otago region. These forests provide valuable supplies of timber for buildings and fencing and are of great importance in any development programme.

Surely the many willow trees growing along water races in Central Otago make for inefficiency of use of irrigation water?

(SMETham): Yes, the willows certainly use water which otherwise would be available for irrigating. but, on the other hand, with the very hot sunny conditions in summer, shade for stock is very important, too. Sheep make use of available shade during the heat of the day although I do not think it is known whether the absence of shade adversely affects stock thrift.

In view of the work done by $\mathrm{Dr}$ McLean at Lincoln on fhe fattening of lambs on pure lucerne, do you consider that your statement that the thrift of lambs on pure lucerne suffers if they do not have access to alternative feed is still correct?

(Sмeтнam): Yes. The basis for the statement lies in the experience of several farmers using dryland lucerne as their main pasture. Several of these men have experienced lack of thrift or growth in lambs at foot on pure lucerne. These farmers now either sow cocksfoot with the lucerne or also sow special blocks of pasture which are fenced in with pure lucerne stands using a ratio of 30 acres pasture to 100 acres lucerne.

Dr McLean did show that lucerne has a relatively low oestrogenic activity in the spring but a high activity in autumn. This might conceivably be a reason for the lack of growth of lambs at foot on pure lucerne in the spring. White clover, on the other hand, Dr McLean showed, had a high oestrogenic activity in the spring and a low activity in the autumn-exactly the reverse of lucerne. 